\title{
DETERMINANTS OF HOUSEHOLD LIVELIHOOD DIVERSIFICATION: A STUDY ON VILLAGES SITUATED NEAR INDO- BHUTAN BORDER OF UDALGURI DISTRICT, ASSAM
}

\author{
Malabika Kalita \\ Assistant professor, Department of Economics, Dimakuchi College, Assam, India
}

\begin{abstract}
This Study is carried out in order to analyse the determinants of livelihood diversification of the inhabitants and the different aspects of socio-economic life of the people living in villages along the Indo-Bhutan border of Udalguri district so that it can come up with definite strategies to pull up the economy of this area. This study made use of both the primary and secondary information to realize the objective. To provide contrast three villages within 0-10 km of distance is selected in the first stage. Thereafter a random sample of 66 households was proportionately allocated among three villages on the basis of the total households in each village. The reference year of the survey was 2017-2018. To study the livelihood diversification an Inverse of Herfindahl- Hirschman Index is used and to study the determinants of livelihood diversification linear censored (Tobit) regression model taking index of livelihood diversification i.e. inverse of HH index as dependent variable is used in the study. It is observed in the study that EEA, SCH, DM, RBA and GEN dummy have significant impact on the livelihood diversification of the study area.
\end{abstract}

Key words: Economy, Livelihood, Livelihood Diversification, Indo- Bhutan border, Livelihood Diversification Index (LDI), Inverse of Herfindahl-Hirschman index.

Cite this Article: Malabika Kalita, Determinants Of Household Livelihood Diversification: A Study On Villages Situated Near Indo- Bhutan Border Of Udalguri District, Assam, International Journal of Management, 11(12), 2020, pp. 835-844. http://iaeme.com/Home/issue/IJM?Volume=11\&Issue=12

\section{INTRODUCTION}

In Development Studies literature, both livelihood and diversification have recently become popular. The term 'Livelihood' refers to a means of living i.e. the financial means whereby one lives. On the other hand 'Livelihood Diversification' refers that people survive by doing many different things rather than just one thing or few things.

Means of living in the villages situated along Indo- Bhutan boarder of Udalguri District are mostly based on agriculture. But due to the frequent conflict between man and elephant, 
lack of water resources, lack of communication viz. poor infrastructure, road connectivity etc, the inhabitants of the villages along Indo- Bhutan boarder area have adopted the practice of tea plantation and other kind of livelihood activities instead of depending on only one or single livelihood activity. Despite of having potentialities, these areas have not felt the impact of economic progress. No major improvement is also seen in the infrastructural facilities even in these areas. Moreover while going through different literature during the course of the study, it is observed that although lots of work has been done on livelihood pattern, livelihood diversification pattern and its determinants in different parts of India and rest of the world, very little work has been done in North Eastern Region in comparison to other parts of India. Moreover no such work has been done in Udalguri district of Assam with special reference to the people living in border villages of Udalguri District.

In this regard the investigator feels that it will be proper to carry out a survey on livelihood diversification pattern along with the determinants of livelihood diversification of people living along the Indo- Bhutan boarder villages of Udalguri district of Assam which certainly will bring out a clear picture of different occupation that these people are adopting for their livelihood. Moreover, the researcher being a resident of the district considers to be her responsibility to have proper information about the lives and livelihood of the people in the area.

Inspired by all the considerations mentioned above, the investigator has chosen to take up the present problem entitled as "Determinants of Household Livelihood Diversification: A Study on Villages Situated Near Indo- Bhutan Border of Udalguri District, Assam.”

\section{LIVELIHOOD DIVERSIFICATION}

Livelihood diversification is an important strategy to help the rural people to come out of poverty. The concept and the working on diversification of livelihoods came up during the 1990s and the most important contributions were made from the Overseas Development Group of the University of East Anglia, led by Frank Ellis. Livelihood diversification is generally a process through which rural families construct a diverse portfolio of different activities to improve their standard of living (Ellis, 1998). In developing countries Ellis defines livelihood diversification as survival strategy which is dynamic and it thus implies a process of constant adaptation.

Thus we can say that livelihood diversification is one of such dynamic phenomena now taking place in rural areas and thus needs more focus and attention from policy makers. For this attempts have been made by individuals and households to find some new ways to increase incomes and reduce risk, which differ sharply by the degree of freedom of choice. The answer to the question of why individuals and households undertake diversification as a livelihood strategy is often divided into two considerations, which are necessity or choice (Ellis, 1998). Necessity refers to some voluntary reasons of diversification whereas choice refers to some involuntary reasons of livelihood diversification. Different scholars mentioned several types of livelihood diversification activities. There are mainly four major rural livelihood strategies generally adopted by household. They were namely on-farm agricultural production, unskilled on-farm or off farm wage employment and non-farm earnings from trades, commerce and skilled employment and the fourth mixed strateg ywhich is the combination of all the three strategies (Kassie, 2017).

\section{AN OVERVIEW OF INDIA - BHUTAN BORDER}

India is located in South Asia and occupies a dominant position in the Northern Indian Ocean. India has a coastline of 7,516.6 km including island territories and land border of 15, $1067 \mathrm{~km}$ 
which it shares with seven countries - Bangladesh, China, Pakistan, Nepal, Myanmar, Bhutan and Afghanistan.

Since the present study is related to villages near Indo- Bhutan border area therefore it mainly discuss about the Border between India and Bhutan. The India - Bhutan border is the international boundary between the Kingdom of Bhutan and republic of India. The total length of the border is $699 \mathrm{~km}$ long and proper demarcation was completed in the year 2006 . The border adjoins the Indian States of Assam, Arunachal Pradesh, West Bengal and Sikkim.

Assam Shares $265.8 \mathrm{~km}$ of international border with Bhutan. Altogether four districts viz. Udalguri, Baksa, Chirang, and Kokrajhar share their boundary to the north with Bhutan. Baksa district is sharing approximately $90 \mathrm{~km}$ of its boundary with Bhutan. Similarly Chirang, Kokrajhar and Udalguri are sharing approximately $70 \mathrm{~km}, 40 \mathrm{~km}$ and $80 \mathrm{~km}$ of its boundary with Bhutan respectively.

\section{OBJECTIVE OF THE STUDY}

To examine the determinants of livelihood diversification of the inhabitants of people living in villages situated near Indo - Bhutan border of Udalguri District.

\section{DATA SOURCE AND METHODOLOGY}

Based on the objective of the present study, both the primary and secondary data have been used for the study purpose. The primary data has been collected through a pretested structured schedule by personal interview method from the sample households. The secondary data has been collected from different sources such as reports prepared by Government and nongovernment organizations, statistical handbook, various published and unpublished journals, research works, and library works etc.

The study adopts a methodology wherein both primary and secondary data have been collected and analyzed. The three stage sampling design is carried out during the course of study. Among 9 Revenue Circles of Udalguri district, two Revenue Circles viz. Harisinga and Udalguri are sharing the international border between India and Bhutan. In the first stage Harisinga Revenue circle of Udalguri District is selected. In the second stage three villages viz. No 1 Rajagarh, No 2 Chamrang and No 3 Tanky Basti were selected randomly. In the next stage data from 66 households are collected randomly from sample villages i.e. $25 \%$ of total households in each village.

The data collected has been analysed using simple tabulation, cross tabulation and statistical tools in the form of percentages, ratios, averages etc. Graphical representations have been worked out with due reference to the context. Based on the requirement of the study, statistical and econometric tools and analysis like index formation etc have been put into use using software like Microsoft Excel, SPSS, STATA etc.

The data collected has been subjected to various statistical and econometric tools depending on the need of the study. For instance to analyse livelihood diversification, inverse of Herfindahl-Hirschman (HH) index has been computed. Again In order to investigate why some households maintain a more diversified income portfolio than others, we carried out a linear censored (Tobit) regression model taking index of livelihood diversification i.e. inverse of $\mathrm{HH}$ index as dependent variable. Heteroscedasticity is tested with the help of BreuschPagan test and the result showed that there is no problem of Heteroscedasticity in the model. Moreover some variable were dropped by the researcher which shows VIF greater than 4 implying the problem of multicolliniarity. 
Determinants Of Household Livelihood Diversification: A Study On Villages Situated Near IndoBhutan Border Of Udalguri District, Assam

\section{FACTORS INFLUENCING LIVELIHOOD DIVERSIFICATION}

\subsection{Independent Variables}

\subsubsection{Landholding (LAND)}

Physical asset ownership like landholding is presumed to determine the ability of a household to diversify. Here we have considered the landholding size in bigha, as it is one of the important factors in farmer's decision to diversify. Landholding size may have both a positive and negative influence.

\subsubsection{Age of the head of the household (AGE)}

Age is an important determinant for the choice of livelihood by a person. One may expect that people with higher age tend to shift less from their present livelihood to other livelihood options. In other words, as the age of the farm household increases, the farmer will be getting older and could not be capable of diversifying as many livelihood activities as possible.

\subsubsection{Economically Active Adults (EAA)}

The number of working hands available in the family is important in determining the extent of diversification to be pursued by the family. Higher availability of workers might enable the households to allocate jobs to its members according to their respective specialization and preferences. In the present study members having age between 15 to 60 years are taken as economically active adults.

\subsubsection{Schooling (SCH)}

Level of education is another important determinant of livelihood diversification of household. With more education people tend to adopt different livelihood activities to earn more income in order to secure their lives. In the present study average schooling of adult members of the household in years is taken as one of the important variables to investigate its impact on household livelihood diversification.

\subsubsection{Distance from Market (DM)}

Households situated near to the market centre are in a better position to avail benefits out of market opportunities and thus diversify their options of income. Hence it is considered that households near to the market centre are more likely to diversify than the households far off. Therefore, distance from nearest weekly market is looked into as an explanatory variable for its possible influence on livelihood diversification.

\subsubsection{Ratio of members having bank account (RBA)}

Having bank account is considered as an important determinant of household livelihood diversification as with the help of banking facility members of the household can take credit and invest in different livelihood activities.

\subsubsection{Migration Dummy (MIG)}

Migration seems to be an important driver of local non-farm diversification, most likely through remittances and returning migrants. The dummy assumes value ' 0 ' if any members of the household have migrated to other state and ' 1 ', otherwise.

\subsubsection{Membership Dummy (MEM)}

Membership of a formal social organization like Self-help Group (SHG)/co-operative/ village committee, etc. is an important social capital in determining livelihood diversification. 
Membership of a SHG elevates his/her social status and increases access to common property resources as well as different government/NGO schemes. In our model the dummy assumes ' 0 ', if the head of the household is a member of any Self-help Group (SHG)/co-operative/ village committee, etc and ' 1 ' otherwise.

\subsubsection{Trade Dummy (TRADE)}

Since the present study is likely to investigate the livelihood diversification of household situated near Indo- Bhutan border of Udalguri district therefore it is expected that the participation of household in border trade to play an important role in determining the livelihood diversification of the households in the study area. In the study the qualitative variable equals to ' 0 ' if any members of the household participates in border trade and ' 1 ' otherwise.

\subsubsection{Gender Dummy (GEN)}

The gender dummy variable represents the gender segregation between men and women household heads. Gender is an integral and inseparable part of rural livelihoods. Men and women have different assets, access to resources, and opportunities. The gender of the head of the households can also influence diversification decisions because of trade-off in labour allocation by women between household chores and highly remunerative activities. We expect that following the results of other studies, women headed households to be more diversified as compared to male headed households. This is because, female-headed households often faces higher insecurity, due to some social reasons which limit their economic activities, and also their lower market wage rate than men. In our regression, qualitative variable equals to ' 0 ' if household head is male and ' 1 ' otherwise.

\subsubsection{Family Status Dummy (FS)}

The status of family i.e. whether the household is joint or nuclear is also an important factor in determining the extent of livelihood diversification to be pursued by the household. Hence it is considered that households with joint family may have greater opportunities to adopt different livelihood options and households with nuclear family compared to the joint family may have lesser opportunities to adopt different livelihood options. Therefore, family status is taken as an explanatory variable in our model for its possible influence on livelihood diversification. The dummy assumes ' 0 ', if the household have nuclear family and ' 1 ' otherwise.

Table 1 Description of variables and expected signs of coefficients

\begin{tabular}{|c|l|l|l|l|l|c|}
\hline \multirow{2}{*}{$\begin{array}{c}\text { Variable } \\
\text { Name }\end{array}$} & \multicolumn{1}{|c|}{$\begin{array}{c}\text { Variable } \\
\text { Description }\end{array}$} & \multicolumn{4}{|c|}{ Descriptive Statistics } & \multirow{2}{*}{$\begin{array}{c}\text { Expected Signs } \\
\text { Of coefficients }\end{array}$} \\
\cline { 3 - 6 } & & Mean & Max & Min & SD & \\
\hline LDI & $\begin{array}{l}\text { Livelihood } \\
\text { diversification index } \\
\text { values of inverse of } \\
\text { HH index) }\end{array}$ & 0.50 & 0.75 & 0 & 0.20 & \\
\hline LAND & $\begin{array}{l}\text { Total landholding of } \\
\text { a household }\end{array}$ & 4.13 & 11 & 0 & 2.43 & \\
\hline AGE & $\begin{array}{l}\text { Age of the } \\
\text { household head }\end{array}$ & 49.4 & 65 & 38 & 5.03 & - \\
\hline
\end{tabular}


Determinants Of Household Livelihood Diversification: A Study On Villages Situated Near IndoBhutan Border Of Udalguri District, Assam

\begin{tabular}{|c|c|c|c|c|c|c|}
\hline EEA & $\begin{array}{l}\text { Economically active } \\
\text { adults of the } \\
\text { household i.e. } \\
\text { members who are } \\
\text { between } 15-60 \text { years }\end{array}$ & 3.88 & 6 & 1 & 1.21 & + \\
\hline SCH & $\begin{array}{l}\text { Average schooling } \\
\text { of adult members of } \\
\text { the household in } \\
\text { years }\end{array}$ & 5.23 & 9 & 1 & 1.83 & + \\
\hline DM & $\begin{array}{l}\text { Distance of a } \\
\text { household } \\
(\text { in } \mathrm{km} \text { ) from the } \\
\text { nearest weekly } \\
\text { market }\end{array}$ & 9.73 & 5 & 21 & 4.59 & - \\
\hline RBA & $\begin{array}{l}\text { Ratio of members } \\
\text { having bank account } \\
\text { (members of the } \\
\text { household who have } \\
\text { bank account divided } \\
\text { by the total family } \\
\text { members) }\end{array}$ & 0.73 & 1 & $\mathbf{0}$ & 0.25 & + \\
\hline MIG & Migration Dummy & N/A & 1 & $\mathbf{0}$ & N/A & + \\
\hline MEM & Membership Dummy & N/A & 1 & $\mathbf{0}$ & N/A & - \\
\hline TRADE & Trade Dummy & $\mathbf{N} / \mathbf{A}$ & 1 & $\mathbf{0}$ & $\mathbf{N} / \mathbf{A}$ & + \\
\hline GEN & Gender Dummy & $\mathbf{N} / \mathbf{A}$ & 1 & $\mathbf{0}$ & $\mathbf{N} / \mathbf{A}$ & $+/-$ \\
\hline FS & $\begin{array}{l}\text { Family Status } \\
\text { Dummy }\end{array}$ & N/A & 1 & $\mathbf{0}$ & $\mathbf{N} / \mathbf{A}$ & + \\
\hline
\end{tabular}

Source: Estimated by the researcher

\subsection{Functional Form of the Model}

Here the dependent variable, the index of livelihood diversification being bounded between 0 and 1, a linear regression model is unsuitable for the present purpose as the predicted value from a linear regression will not necessarily be contained within the interval of 0 and 1 . Considering that there are a cluster of households with the $\mathrm{HH}$ index taking the value 1 , a censored Tobit model with censoring on left side has been formulated.

The model is formulated with the help of latent variable $\mathrm{Yj}^{*}$ which can take any possible value but is not always observable. Incorporating the above mentioned explanatory variables, $\mathrm{Yj}^{*}$ has been formulated as:

$$
\begin{gathered}
\mathrm{Yj}^{*}=\mu 0+\mu 1 \mathrm{LAND}+\mu 2 \mathrm{AGE}+\mu 3 \mathrm{EEA}+\mu 3 \mathrm{SCH}+\mu 4 \mathrm{DM}+\mu 5 \mathrm{RBA}+\mu 6 \mathrm{MIG} \\
+\mu 7 \mathrm{MEM}+\mu 8 \mathrm{TRADE}+\mu 9 \mathrm{GEN}+\mu 10 \mathrm{FS}+\mathrm{Uj} \ldots \ldots \ldots \ldots \ldots . . . . . . .1
\end{gathered}
$$

Where the random disturbance $\mathrm{Uj}$ s are assumed to be independently normally distributed with zero mean. 
The observed dependent variable Yj (i.e. index of livelihood diversification, i.e., inverse of $\mathrm{HH}$ index for the jth sample household) is linked to the latent variable $\mathrm{Yj}^{*}$ the following formulation:

$$
\begin{aligned}
& Y j=Y j^{*} \text { for } Y j^{*}>0 \\
& Y j=0 \text { for } Y j^{*} \leq 0
\end{aligned}
$$

The model specified in equation (1) is estimated by Maximum Likelihood method using STATA.

\subsection{Results and Discussion}

We find in the result that our predictors are, in most cases, related to diversification in the ways suggested by theory. In other words, the results are in line with our expectation in most of the cases. The estimated model is tested in order to see if the model suffers from the problem of heteroscedasticity or not by Breusch- Pagam test. The results showed that the estimated model is free from the problem of heteroscedasticity.

The regression results of censored (Tobit) model specified in equation (1) are reported in Table2. The empirical results in Table(2) indicates that the estimated coefficient for LAND (size of holding land) is negative as expected and highly significant at less than 1 per cent level of significance indicating that the size of holding land by each household have a negative and significance influence on livelihood diversification.

\begin{tabular}{|c|c|}
\hline Variables/Items & $\begin{array}{c}\text { Estimated coefficients } \\
\text { (standard error) } \\
\{\text { p value }\}\end{array}$ \\
\hline LAND & $\begin{array}{c}-0.07^{* * *} \\
(0.006) \\
\{0.00\}\end{array}$ \\
\hline AGE & $\begin{array}{l}-0.005 \\
(0.001) \\
\{0.751\}\end{array}$ \\
\hline EEA & $\begin{array}{c}0.02^{*} \\
(0.01) \\
\{0.095\}\end{array}$ \\
\hline $\mathrm{SCH}$ & $\begin{array}{l}0.01^{* * *} \\
(0.006) \\
\{0.009\}\end{array}$ \\
\hline DM & $\begin{array}{l}-0.003^{*} \\
(0.002) \\
\{0.099\}\end{array}$ \\
\hline RBA & $\begin{array}{c}0.08^{* *} \\
(0.03) \\
\{0.020\}\end{array}$ \\
\hline MIG & $\begin{array}{c}-0.01 \\
(0.02) \\
\{0.433\}\end{array}$ \\
\hline
\end{tabular}

Table 2 Censored Regression (Tobit) Results of Livelihood diversification 
Determinants Of Household Livelihood Diversification: A Study On Villages Situated Near IndoBhutan Border Of Udalguri District, Assam

\begin{tabular}{|l|c|}
\hline MEM & -0.009 \\
& $(0.02)$ \\
& $\{0.57\}$ \\
\hline TRADE & 0.001 \\
& $(0.005)$ \\
& $\{0.92\}$ \\
\hline FS & -0.05 \\
& $(0.032)$ \\
& $\{0.099\}$ \\
\hline Constant & -0.01 \\
& $(0.02)$ \\
& $\{0.268\}$ \\
\hline Pseudo R2 & $0.61^{* * *}$ \\
& $(0.09)$ \\
\hline LR chi2 (11) & $\{0.00\}$ \\
\hline Log Likelihood & 11.77 \\
\hline Number of observations & $188.83^{* * *}$ \\
\hline
\end{tabular}

\subsection{Note}

- 8 left-censored observations at $\mathrm{LDI}<=0$

- *,**,***, indicate significant at $10 \%, 5 \%$ and $1 \%$ respectively.

- Figures within ( ) are respective standard errors.

- Figures within \{\} are respective $p$ values or level of significance.

The estimated coefficient of AGE (age of the head of the household) is not significant but the sign of estimated coefficient is similar to our expectation.

The estimated coefficient of EEA (economically active adults) is found to have significant and positive influence on livelihood diversification. This finding confirms that more number of working members in the rural household has better chances to adopt different livelihood activities.

The variable SCH (average schooling of adult members of the household in years) is observed to have significant impact on livelihood diversification. This is due to the fact that with higher level of education, households adopt different livelihood option to earn more income and to reduce risk.

The estimated coefficient of DM (distance of household to nearest weekly market) is significant at 10 per cent level of significance and has negative impact on livelihood diversification. This is owing to the fact that distance from market centre hinders the households diversifying into different livelihood options while nearness stimulates diversification.

Again, the estimated coefficient of RBA (ratio of members having bank account to total family members) has significant positive influence on livelihood diversification. This is 
because with the help bank account a household can take different banking facilities such as taking loan to start a business or investing in some other livelihood option.

Again, if we consider the qualitative variables in the estimated model, the results in Table (2) shows that except GEN (gender dummy), and the other variables viz. MIG (migration dummy), MEM (membership dummy), TRADE (border trade dummy) and FS (family status dummy) are all insignificant. The variables MIG, MEM and FS dummy have insignificant but negative influence on dependent variable i.e., index of livelihood diversification. TRADE dummy is expected to have significant positive impact on the livelihood diversification of the study area as the study is concerned with people living in border area of Indo - Bhutan border. But the estimated coefficient of TRADE dummy is not significant. This might be due to the fact that out of three sample villages only the No 2 Chamrang village have route to Bhutan and while the rest of the two villages have not. The GEN dummy is significant but negative influence on livelihood diversification indicating that the predicted value of livelihood diversification is 0.05 points lower for female headed household than for male headed households.

The likelihood ratio chi-square (LR chi2) of the model is found to be $188.83(d f=11)$ which is significant at less than 1 per cent level showing the overall significance of the model. Thus the model gives a fairly good fit, keeping in view the cross section nature of the data set used.

\section{CONCLUSION}

The households across the study villages who are able to access the market, getting education facility, and proper infrastructure are also able to diversify in terms of livelihood options. But there is also a significant section of the sampled households in the study area who have not been able to diversify because of various factors like illiteracy, untrained farming, very small size of land holding, underdeveloped transport and communication facility, lack of marketing facility of agricultural products, lack of irrigation facility etc. Moreover it is observed during the study that the main obstacle which the inhabitants of this area face is frequent conflict between man and elephant along with wild pig, peacock etc. Every year this conflict cause havoc to these peoples in this area. Among the three villages this problem is prevalent but another problem that also has been creating obstacles is the huge scarcity of water in No 1 Rajagarh and No 3 Tanky Basti of the study area which results in the lower production of food crops mainly rice.

Like any other studies, it has its own limitations. In particular, further research is required to extend the study in order to provide more systematic longitudinal analyses of livelihood changes, the and processes of diversification. Limited time, financial and other resources available did not permit such analyses, which are obvious gaps in this research. Thus, there is a huge scope to carry out some of these analyses in future. Hence, this would help to gain a fuller understanding of livelihood diversification pattern in the villages situated near IndoBhutan border of Udalguri district than this research has been able to provide.

\section{REFERENCES}

[1] Adepoju, O. Abimbola., \& Oyewole, O. Olanyi. (2014). Rural Livelihood Diversification and Income Inequality in Local Government Area Akinyele, Ibadan, Oyo State, Nigeria. Journal of Agricultural Sciences, 59(2): 175-186.

[2] Asmah, E, E. (2011). Rural Livelihood Diversification and Agricultural Household Welfare in Ghana. Journal Of Development And Agricultural Economics, 3(7): 325-334 
Determinants Of Household Livelihood Diversification: A Study On Villages Situated Near IndoBhutan Border Of Udalguri District, Assam

[3] Baby, Smitha., Helen, S. (2015). Analysis of Livelihood Diversification among Farming Community- Towards a Livelihood Based Extension Approach. International Journal of Home Science Extension and Communication Management, 2(1): 18-21

[4] Ellis, F. (1998). Household Strategies and Rural Livelihood Diversification. Journal of Development Studies, 35(1): 1-38.

[5] Kassie, W, G. Kim, S. Fellijar, P, F. (2017) Determinant factors of livelihood diversification: Evidence from Ethiopia.[Online] Available: www.tandfonline.com[Accessed on 2nd March 2018]

[6] Sujithkumar, S, P. (2007), 'Livelihood Diversification: A Case Study in Rural Tamil Nadu', The Indian Journal Of Labour Economics, 50 (4): 1-8 